\title{
Biometric Study of Furcation Area of First Maxillary Molars
}

\author{
Giuseppe Alexandre ROMITO \\ Francisco Emílio PUSTIGLIONI \\ Department of Periodontics, University of São Paulo, São Paulo, SP, Brazil
}

\begin{abstract}
The present investigation was designed to study the distance from the 3 bifurcation entrances to their opposite roots, and also the virtual center of the trifurcation (TC), which is equidistant from each bifurcation entrance, of maxillary molars. Thirty-five teeth devoid of any surface damage or fused roots were selected. Roots were included in acrylic resin and cross-sectioned at the cementoenamel junction to the apex using a rotary diamond blade and $0.45-\mathrm{mm}$ slices were obtained. A profile projector apparatus was used to obtain the coordinated points on a Cartesian plane, which allowed the calculation of all distances present using analytic geometric formulas. Based on statistical analysis (comparison by Kruskal-Wallis ANOVA test, $\mathrm{p}<0.05$ ), the following results were obtained: 1 ) mean distance from the buccal furcation reaching the palatal root was $6.72 \pm 0.99 \mathrm{~mm}$ (range 4.73-8.67 mm); 2) mean distance from the mesial and distal furcations to the distal and mesial roots were $5.42 \pm 0.83 \mathrm{~mm}$ (range 3.78-7.07 mm) and 5.90 $\pm 0.87 \mathrm{~mm}(\mathrm{range} 4.18-7.59 \mathrm{~mm}$ ), respectively. All means were determined up to the point of $1.40 \mathrm{~mm}$ from each bifurcation opening; 3 ) mean distance of TC was 4.26 $\pm 0.42 \mathrm{~mm}$ (range 3.44-5.08 $\mathrm{mm}$ ) for all levels.
\end{abstract}

Key Words: tooth root/anatomy, bifurcation/trifurcation diagnosis.

\section{INTRODUCTION}

Management of molars with furcation involvement represents one of the major problems in clinical periodontology. Both prognosis and choice of therapy depend on the degree of furcation involvement (1). Clinical radiographic exams are indispensable to obtain all necessary data (2) for good prognosis of individual teeth as well as to determine appropriate treatment for lesions related to bi- and trifurcations of maxillary molars. Therefore, knowledge of the anatomy of these areas is extremely important (3-5).

The aim of the present study was to determine: a) the distance from the entrance of each bifurcation to the opposite root: buccal furcation entrance to palatal root (Bfe-Pr), mesial furcation entrance to distal root (MfeDr), and distal furcation entrance to mesial root (Dfe$\mathrm{Mr})$; b) trifurcation center (TC).

\section{MATERIAL AND METHODS}

Thirty-five maxillary first molars were selected from a collection of extracted teeth. The selection criteria excluded those teeth with fused roots. The teeth were cross-sectioned at the cementoenamel junction (CEJ) and roots were embedded in blocks of self-curing acrylic resin. Each block was cross-sectioned at 0.45 $\mathrm{mm}$ increments with a thin diamond blade on a sectioning machine (Labcut 1010, Extec Corp., Enfield, CT, USA) from the CEJ to the apex. Coronal and apical sides of each section were identified (Figure 1, left) and analyzed with a profile projector apparatus (Profile projector PJ 300, n. 302-912-A, Mitutoyo Corp. Tokyo, Japan). Coordinated points were determined $\left(\mathrm{P}_{1}, \mathrm{P}_{2}, \mathrm{P}_{3}\right.$, ..., $\mathrm{P}_{\mathrm{n}}$ ) (Figure 1, right). These points allowed the calculation of all distances needed, provided by analytic geometric formulas. Formula "A" was used to calculate the distances from the furcation entrance to its opposite roots $\left\{\right.$ Formula $\left.\mathrm{A}: \mathrm{d}_{(\mathrm{M}, \mathrm{P} 3)}=\left[\left(\mathrm{x}_{\mathrm{m}}-\mathrm{x}_{3}\right)^{2}+\left(\mathrm{y}_{\mathrm{m}}-\mathrm{y}_{3}\right)^{2}\right]^{1 / 2}\right\}$ and formula "B" was used for TC calculation \{Formula B: $\left.\mathrm{r}=\mathrm{m} \cdot \mathrm{m}_{1} \cdot \mathrm{m}_{2} / 4\left[\mathrm{p}(\mathrm{p}-\mathrm{m}) \cdot\left(\mathrm{p}-\mathrm{m}_{1}\right) \cdot\left(\mathrm{p}-\mathrm{m}_{2}\right)\right]^{1 / 2}\right\}$, where $\mathrm{m}=$ distance between $M$ and $M_{1} ; m_{1}=$ distance between $M_{1}$ and $\mathrm{M}_{2} ; \mathrm{m}_{2}=$ distance between $\mathrm{M}_{2}$ and $\mathrm{M} ; \mathrm{p}=$ semiperimeter of $\mathrm{MM}_{1} \mathrm{M}_{2}$ triangle. 
Data were analyzed using the statistical package SPSS/PC+. The Kruskal-Wallis test (6) was used to compare the different levels of the specimens $(\mathrm{p}<0.05)$.

\section{RESULTS}

The results of the statistical analysis are reported in Table 1, which shows the levels on the roots where the slices were cut. Level 0.00 represents where the bifurcation opening could be first seen with the profile apparatus indicating the trifurcation roof.

Statistical analysis showed that the distances Bfe-Pr and Mfe-Dr must be divided into two groups. The first group goes from $0.00 \mathrm{~mm}$ up to $1.40 \mathrm{~mm}$ and the second group from $1.90 \mathrm{~mm}$ up to $5.20 \mathrm{~mm}$. However, there were no statistical differences among the levels for Dfe-Mr and TC.

Table 2 shows the number of slices analyzed and means $\pm \mathrm{SD}$ of each group.

\section{DISCUSSION}

Diagnosis and treatment of furcation involvement are a challenge. The prevalence of furcation involved molars is higher in the maxilla than in the mandible and, from the age of 30 years, about $50 \%$ of the 1st and 2nd molars in the maxilla show at least 1 furcation site with deep involvement (7).
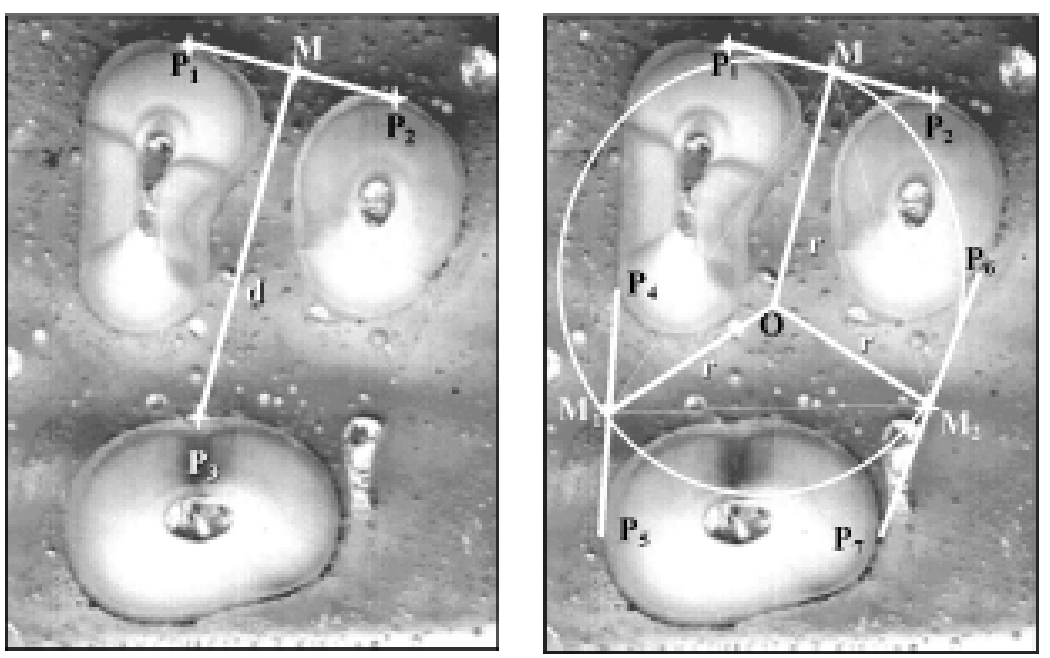

Figure 1. Left panel: Slice showing the 3 roots of a maxillary molar. $\mathrm{P}_{1}, \mathrm{P}_{2}$ and $\mathrm{P}_{3}$ tangents on the root surface. $\mathrm{M}$ is the middle point from the segment P1-P2. $\mathrm{d}$ is the distance between $\mathrm{M}$ and $\mathrm{P}_{3}$.

Right panel: Slice showing all the points $\mathrm{P}$ determined and the graph obtained using the formula "B".
When the classification of bifurcation involvement proposed by Glickman (8) is analyzed, it suggests a classification divided in 4 degrees. This classification is considered the first one addressing bifurcation involvement, being similar for maxillary or mandibular molars. Hamp et al. (1) described a classification for bifurcation involvement, upon which they based all indications for therapy of 310 mandibular and maxillary molars studied over a period of 5 years. Other authors $(9,10)$ offered only suggestions of classifications for bifurcation area. Moreover, all classifications found in the literature evaluate the bifurcation involvement only in its horizontal periodontal loss of attachment (1,8,11-13). However, the horizontal periodontal loss should be considered together with the vertical component as suggested by Tarnow and Fletcher (14). These classifications are not based on a defined scientific methodology, they are only suggestions of classification. Actually, no study analyzed a reliable sample of teeth and made bifurcation measurements to determine and standardize the values of the distances between the bi- and/or trifurcation. They were based on the author's clinical observations.

Another important factor to point out is that all classifications are predominantly used for mandibular molars. It is important to remember that such lesions involve an area between two roots only. Therefore, there is no doubt about the presence of horizontal loss of attachment, but when a maxillary molar is being analyzed an adaptation of the existing classifications is necessary.

There is another difficult aspect in establishing the diagnosis of the trifurcation area. When clinically probing the area, one may not know if the value found is the distance up to the opposite root of that bifurcation, or if it is the bone still present in that area.

Rosenberg (15) also suggests a classification for maxillary molars based on the accumulation of approximately 100 maxillary and mandibular molars that were removed because of periodontal pathology. The author considered the horizontal, vertical and internal components of the trifurcation. The internal furcation is designated as shallow or deep. The shallow internal furcation in- 
Table 1. Distances from 3 buccal bifurcation entrances to their oppoiste roots and the trifurcation center.

\begin{tabular}{|c|c|c|c|c|c|c|c|c|c|c|c|c|c|c|}
\hline \multirow[t]{2}{*}{ Level } & \multicolumn{4}{|c|}{ Distance from Bfe-Pr } & \multicolumn{4}{|c|}{ Distance from Mfe-Dr } & \multicolumn{3}{|c|}{ Distance from Dfe-Mr } & \multicolumn{3}{|c|}{ Trifurcation Center } \\
\hline & $\mathrm{N}$ & Mean & SD & & $\mathrm{N}$ & Mean & SD & & $\mathrm{N}$ & Mean & SD & $\mathrm{N}$ & Mean & SD \\
\hline 0.00 & 35 & 6.20 & $\overline{0.97}$ & & 35 & 4.97 & $0.69_{7}$ & & 35 & 5.53 & 0.83 & 35 & 4.19 & 0.447 \\
\hline 0.45 & 35 & 6.55 & 0.93 & & 35 & 5.23 & 0.75 & & 34 & 5.66 & 0.90 & 34 & 4.25 & 0.41 \\
\hline 0.95 & 34 & 6.98 & 0.85 & (1) & 35 & 5.66 & 0.75 & $\begin{array}{l}* \\
(1)\end{array}$ & 34 & 5.91 & 0.77 & 33 & 4.24 & 0.40 \\
\hline 1.40 & 33 & 7.21 & 0.93 & & 34 & 5.83 & 0.881 & & 32 & 6.04 & 0.91 & 31 & 4.26 & 0.41 \\
\hline 1.90 & 28 & 7.51 & 0.92 & & 28 & 6.08 & 0.80 & & 21 & 6.19 & 0.88 & 20 & 4.33 & 0.40 \\
\hline 2.35 & 26 & 7.65 & 0.98 & & 28 & 6.09 & 0.94 & & 20 & 6.27 & 0.89 & 18 & 4.38 & 0.36 \\
\hline 3.30 & 18 & 7.90 & 1.03 & * & 18 & 6.26 & 0.89 & & 11 & 5.90 & 0.76 & 8 & 4.25 & 0.30 \\
\hline 3.80 & 8 & 8.15 & 1.09 & (2) & 8 & 6.20 & 0.89 & $\begin{array}{l}\boldsymbol{x} \\
(2)\end{array}$ & 5 & 6.04 & 0.70 & 5 & 4.27 & 0.39 \\
\hline 4.25 & 4 & 8.33 & 0.78 & & 4 & 6.16 & 0.87 & & 4 & 5.97 & 0.99 & 4 & 4.20 & 0.37 \\
\hline 4.75 & 3 & 8.25 & 0.56 & & 3 & 5.89 & 0.73 & & 2 & 5.54 & 0.88 & 2 & 3.92 & 0.37 \\
\hline 5.20 & 2 & 8.14 & 0.73 & & 2 & 5.32 & 1.70 & & & & & & & \\
\hline
\end{tabular}

Data are reported as mean \pm SD.

$\mathrm{N}=$ number of slices at each level analyzed.

] no significant differences.

]* Significant differences between groups (1) and (2). See text for explanation.

Table 2. Means \pm SD of distances for each group.

\begin{tabular}{|c|c|c|c|c|c|c|}
\hline Values & \multicolumn{6}{|c|}{ Distances } \\
\hline & Bfe-Pr (1) & Bfe-Pr (2) & Mfe-Dr (1) & Mfe-Dr (2) & Dfe-Mr & TC \\
\cline { 2 - 7 } N & 137 & 110 & 139 & 112 & 211 & 200 \\
\hline Mean & 6.74 & 7.98 & 5.42 & 6.03 & 5.92 & 4.26 \\
\hline SD & 0.99 & 0.98 & 0.84 & 0.88 & 0.87 & 0.42 \\
\hline
\end{tabular}

$\mathrm{N}=$ number of slices analyzed of each group.

volvement is defined as the slight lateral extension of an interradicular defect, from the center of the trifurcation in a horizontal direction, toward one or both adjacent furcations. The deep internal furcation involvement denotes the greater lateral extension of the interradicular defect into but not penetrating the adjacent furcation.

In accordance with the results of Rosenberg (15), the distance of the buccal bifurcation to the center would be $4 \mathrm{~mm}$. In spite of mentioning this value, the classification proposed by the author does not use this data. It classifies the internal involvement of the area as shallow or deep. This internal component would just be considered when the horizontal component was classified as Grade II or III. In this manner, the internal component would be directly related to the therapy to be used in the maxillary molars with bifurcation lesions.

It is evident that knowledge of both the distance between the entrance of the bifurcation and the center of the trifurcation are necessary for a good diagnosis. With the results of this study, it was possible to precisely define the distance from the bifurcation to the opposite roots as well as to the trifurcation center.
With the measures of Bfe-Pr, Mfe-Dr and Dfe-Mr, it is possible to evaluate, separately, the degree of involvement of each bifurcation. In this way, we can obtain the clinical horizontal attachment loss for each. One cannot forget that the measures can be overestimated.

With the mean value of $4 \mathrm{~mm}$ for the trifurcation center, three degrees of furcation involvement can be defined. When the result of probing is not larger than $4 \mathrm{~mm}$, the lesion is classified as degree I. When probing shows a value larger than $4 \mathrm{~mm}$ (i.e., the bifurcation lesion has already passed the center of the trifurcation), the classification is degree II. Degree III means that two or three furcations classified as degree II were found.

The results of the measurements Bfe-Pr, Mfe-Dr and Dfe-Mr complete TC measurement when there is either the involvement in degree II or III that are proposed in this study. The values of the measures Bfe-Pr, Mfe-Dr and Dfe-Mr are useful because they define the distance of the opposite root, since values larger than 4 $\mathrm{mm}$, without any other information, allow establishing the involvement degree only.

The analysis of the degree of involvement of maxillary molar trifurcation, along with the knowledge of the values of the distance from bifurcations to the opposite root, can make diagnosis easier. It also facilitates the evaluation of the most appropriate therapy to be applied, in agreement with Al-Shammari et al. (16), who concluded that the treatment approaches for furcation-involved molars must be based on the degree of 
involvement.

The decision for a specific treatment for a periodontitis-affected furcation certainly depends on several factors. Tooth type and degree of furcation involvement may be regarded by the majority of therapists as the most important factors influencing the decision for one or other treatment mode (17). One of these treatments is guided tissue regeneration. Most studies report favorable results in class II mandibular furcations $(18,19)$, while less favorable results were found in class III mandibular defects and class II maxillary defects (20). The results of this study could help to obtain a better diagnosis and/or understanding of the morphology of the furcation defect, so treatment of a maxillary molar furcation could be better chosen.

Besides guiding treatment, the standardization of the measurements of furcation lesions of maxillary molars is necessary to enable the comparison of results obtained with different treatment methods and techniques. In the absence of standardization, it is impossible to compare studies from different authors.

\section{RESUMO}

O presente estudo objetivo analisar biometricamente a distância das entradas das 3 bifurcações do primeiro molar superior até a respectiva raiz oposta e determinar o centro da trifurcação $(\mathrm{CT})$, este o ponto eqüidistante da entrada de cada bifurcação. Trinta e cinco dentes livres de qualquer dano superficial e sem raízes fusionadas foram selecionados. As raízes foram incluídas em resina acrílica e seccionadas a partir da linha esmalte-cemento até a porção mais apical usando um disco de diamante. Fatias de 0,45 $\mathrm{mm}$ foram obtidas. Com o auxílio de um perfilômetro digital foram determinadas coordenadas de pontos num plano cartesiano. Isto permitiu o cálculo das distâncias desejadas utilizando fórmulas de geometria analítica. Após a análise estatística (Kruskal-Wallis ANOVA test, $p<0,05)$ obtivemos os seguintes resultados: 1) distância media da entrada da furca vestibular até a raiz palatina foi de 6,72 \pm 0,99 $\mathrm{mm}$ (intervalo de 4,73-8,67 mm); 2) distância media da entrada da furca mesial até a raiz distal e da bifurcação distal até a raiz mesial foi de 5,42 $\pm 0,83 \mathrm{~mm}$ (intervalo de 3,78$7,07 \mathrm{~mm}$ ) e $5.90 \pm 0.87 \mathrm{~mm}$ (intervalo de 4,18-7,59 mm), respectivamente. Todos estes valores foram determinados até $1,40 \mathrm{~mm}$ do teto da trifurcação; 3 ) a média de CT foi de 4,26 \pm $0,42 \mathrm{~mm}$ (intervalo de $3,44-5,08 \mathrm{~mm}$ ) para todos os níveis.

\section{ACKNOWLEDGMENTS}

The authors wish to thank Ana Vitória Imbronito for her constant assistance.

\section{REFERENCES}

1. Hamp S, Nyman S, Lindhe J. Periodontal treatment of multirooted teeth. Results after 5 years. J Clin Periodontol 1975;2:126-135.

2. Ricchetti PA. A furcation classification based on pulp chamberfurcation relationships and vertical radiografic bone loss. Int J Periodont Restorative Dent 1982;2:51-59.

3. Gher ME, Vermino AR. Root morphology-clinical significance in pathogenesis and treatment of periodontal disease. J Am Dent Assoc 1980;101:627-633.

4. Baina RB. Considerations for furcation treatment. Part I: Diagnosis and treatment planning. J Prosthet Dent 1986;56:138-142.

5. Mardam-Bey W, Majzoub Z, Kon S. Anatomic considerations in the etiology and management of maxillary and mandibular molars with furcation involvement. Int J Periodontics Restorative Dent 1991;11:399-410.

6. Siegel S. Nonparametric Statistics for Behavioral Sciences. $1^{\text {st }}$ ed. São Paulo: Editora McGraw-Hill; 1975.

7. Svärdström G, Wennström JL. Prevalence of furcation involvements in patients referred for periodontal treatment. J Clin Periodontol 1996;23:1093-1099.

8. Glickman I. Clinical Periodontology. Philadelphia: WB Saunders Co., 1958. p 694-696.

9. Bower RC, Henry PJ. Furcation involvement - a suggested rationale for treatment. Aust Dent J 1978;23:322-327.

10. Eskow RN, Kapin SH. Furcation invasions: correlating a classification system with therapeutic considerations. Part I. Examination, diagnosis, and classification. Compend Contin Educ Dent 1984;5:479-487.

11. Easley JR, Drennan GA. Morphological classification of the furca. J Can Dent Assoc 1969;35:104-107.

12. Staffileno HJ. Surgical management of the furca invasion. Dent Clin N Am 1969;13:103-119.

13. Lindhe J. Textbook of Clinical Periodontology. Copenhagen: Munksgaard, 1989. 648p.

14. Tarnow D, Fletcher P. Classification of the vertical component of furcation involvement: short communication. J Periodontol 1984;55:283-284.

15. Rosenberg MM. Management of osseous defects, furcation involvements, and periodontal-pulpal lesions. In: Clark JW. ed. Clinical Dentistry - Periodontal and Oral Surgery. Vol. 10. Philadelphia: Harper \& Row, 1986. p 108-117.

16. Al-Shammari KF, Kazor CE, Wang, H. Molar root anatomy and management of furcation defects. J Clin Periodontol 2001;28:730740 .

17. Müller H, Eger T. Furcation diagnosis. J Clin Periodontol 1999;26:485-498.

18. Pontoriero R, Nyman S, Lindhe J, Rosenberg E, Sanavi F. Guided tissue regeneration in the treatment of furcation defects in man. $\mathrm{J}$ Clin Periodontol 1987;14:618-620.

19. Caffesse RG, Smith BA, Duff B, Morrison EC, Merrill D, Becker W. Class II furcations treated by guided tissue regeneration in humans: case reports. J Periodontol 1990;61:510-514.

20. Metzler DG, Seamons BC, Mellonig JT, Gher ME, Gray JL. Clinical evaluation of guided tissue regeneration in the treatment of maxillary class II molar furcation invasions. J Periodontol 1991;62:353-360. 